\title{
抗原浮動と抗原スイッチ一逃げ続ける病原体の戦略
}

\author{
九大理学部生物 佐々木 顕
}

\begin{abstract}
Following infection to a host, some pathogens repeatedly alter their antigen expression to escape the immune defense (antigenic drift/switching). Assuming that most mutations are deleterious but a minor fraction of which can alter the antigenic property of the pathogen, I examine the evolutionarily stable mutation rate, $\mu E S S$, of pathogens which maximizes the stationary pathogen density in a host. The model reveals that: (1) If the mutation rate is higher than a threshold $\mu c$, pathogens cannot maintain themselves because too much progenies are lost by lethal mutations. (2) If the mutaiton rate lies between zero and $\mu c$, the system converges to a traveling wave of antigen variants with a constant wave speed. (3) The $\mu$ ESS is unexpectedly high: more than 0.25 per genome per replication even if most mutations are lethal. I also examine the optimal schedule of pathogen growth in a host.
\end{abstract}

antigen switching/antigenic drift/evolutionarily stable mutation rate/error catastroph/RNA virus

寄主免疫系の激しい攻撃にさらされながら増殖しな ければならない病原体は, 数々の巧妙な戦略を進化さ せてきた。たとえば，トリパノソーマやウマ伝染性筫 血症ウイルスは，感染後に表面抗原を頻繁に変えて抗 原特異的な免疫応答から逃げ続ける（抗原スイッチ・ 抗原浮動). また，エイズウイルスを含むレンチウイ ルスの仲間は，白血球など移動性の寄主細胞内に潜伏 して活動を停止してしまい, 免疫系から何らとがめら れることなく他組織や他個体に進出・伝播する(“ト ロイの木馬”戦略).ここでは, 抗原浮動や坑原ス イッチによって免疫防御機構から逃げ続ける病原体を とりあげ，寄主体内での個体群動態をモデル化するこ とによって，持続的感染のための条件や，抗原変異が 拡大・伝播する過程, 病原体突然変異率の進化などを 論しる.

\section{トリパノソーマの抗原スイッチ (antigen switching)}

単細胞の原虫トリパノソーマは, アフリカで猛威を ふるっている睡眠病の病原体である. ツェツェバエの 媒介によってヒトや家畜の血中に侵入した原虫は，細

The Evolution of Antigen Drift and Switching : Continuously Evading Pathogens.

Akira SASAKI

Department of Biology, Faculty of Science, Kyushu University. 胞表面を覆う糖蛋白質（variant surface glycoprotein, VSG）を次々と脱ぎかえることによって免疫系の攻撃 から逃れる. 感染したトリパノソーマの表面抗原を認 識した免疫系が, 抗体を大量生産してトリパノソーマ を駆逐しようかという時，その抗体の結合できない新 しい表面抗原をもつ変異体が出現して増えはじめるの である，症状はぶり返し，それがおさまる頃にはまた 次の表面抗原体が出現する.この繰り返しのなかでト リパノソーマは增殖を続け，最終的に寄主が衰弱して 死ぬまでに多くのトリパノソーマが他の寄主個体へと 感染する.

トリパノソーマの抗原スイッチ（antigen switching) は表面抗原 VSG をコードする多重遣伝子族内の遺伝 子変換による．発現座位上にあって転写されていた VSG 遺伝子が, ゲノム中に数百コピー以上貯えられ ている非発現座位上の VSG 遺伝子のひとつと置き換 わるのである ${ }^{1 / 2)}$. 回帰熱の病原体 Borrelia や, りん病 の病原体 Neisseria gonorrhoeae, サルモネラ菌やバク テリオファージ $\mu$ なども，やはりゲノム内の抗原レ パートリーを使って抗原スイッチを行う ${ }^{3), 4)}$

\section{ウマ伝染性賓血症ウイルスの抗原浮勤 (antigenic drift)}

ウマ伝染性筫血症ウイルス（EIAV）はレトロウイ ルス科レンチウイルス亜科に属し, 古くから病理学的 研究の進んでいるウイルスである. EIAVに感染した 
ウマは 4-5 週間の間隔をおいてやってくる高熱に何 度も恼まされる，発熱のピークは体内のウイルス粒子 密度のピークに対応しており，各ピーク時に採取した ウイルスの抗原性は異なっている(抗原浮動)。ある 発熟ピーク時のウイルスを中和する抗体が，他のピー ク時のウイルスは中和できないのである. EIAVの抗 原性はふたつの表面糖蛋白質 $\mathrm{gp} 90$ と $\mathrm{gp} 45$ とによって 決定されるが，これらの表面抗原の塩基配列および立 体構造は各発熱ピークごとに微妙なずれを示していた。 つまり，EIAVもトリパノソーマと同様に表面抗原型 を次々と変えることによって免疫系の攻撃から逃れ， 持続的な感染を行うのである. ただし，トリパノソー マが抗原遺伝子のレパートリーを使って遺伝子をまる ごと交換してしまうのに対し，EIAVの抗原型の変化 は表面抗原遺伝子上の点突然変異（塩基置換）や塩基 挿入・次失によると考えられている（以上文献 5 参 照).

EIAV と同じくレンチウイルスに属するvisna ウイ ルスや, エイズウイルス（HIV-1）なども，その表面 抗原遺伝子に降る高頻度の突然変異によって感染後の 寄主体内に多様な抗原型を生む ${ }^{33,61,7)}$.

\section{逃げ続ける病原体と免疫系の動態}

トリパハソーマやEIAVなど“逃げ続ける病原体” の寄主体内での動態をモデル化しよう ${ }^{8}$. 病原体の抗 原型を整数 $k$ で標識し，表面抗原の型 $k$ をむ病原体 の寄主体内密度を $n_{k}(t)$, この表面抗原に特異的な抗 体を産出する B 細胞の体内密度を $B_{k}(t)$ とする. $t$ は 感染後の時間である，病原体の内的増加率を $r$ とする， 抗原性の变化と免疫応答については以下のように仮定 しょう.

（i）ある抗原をもつ病原体は，対応する抗体産生細胞 の密度に比例した速度で破壊される.

(ii) ある表面抗原型に対する抗体産生細胞は，最初か らごくわずか存在し $\left(B_{k}(O)=B_{0}\right)$, その抗原をもつ病 原体の密度に比例した率で增加する.

(iii) 単位時間に病原体 1 個体から $\mu$ の確率で突然変異 体が生じる。ただし，全突然変異のうちで $p$ の割合 $(0$ <p<1)だけが新しい表面抗原型を作りだし，残りは 有害(致死)であるとする。

(iv) 抗原型は一次元格子灴間に並び，笑然変異によっ て抗原型 $k$ が隣接する抗原型 $k+1$ あるいは $k-1$ に変 わる。

以上の仮定によって，各抗原型の病原体と抗体産生細 胞の密度の時間変化は

$$
\begin{aligned}
& d n_{k} / d t=\left(r-\beta B_{k}\right) n_{k}+\mu\left[p\left(n_{k+1}+n_{k-1}\right) / 2-n_{k}\right], \\
& d B_{k} / d t=\alpha n_{k} B_{k} .
\end{aligned}
$$

で表される( $\alpha$ と $\beta$ は免疫応答の強さを表す正のパラ メータ). 右辺第一項は増殖と免疫応答による変化, 第二項は突然変異による変化を表している.

\section{抗原変異の進行波}

抗原型のインデックス $k$ を連続変数として近似する ことにより，抗原型格子空間 $\{k ; k=0, \pm 1, \pm 2$, $\cdots \mid$ 上の動態(1)は, 偏微分方程式

$$
\begin{aligned}
\frac{\partial n(t, k)}{\partial t} & =[r-\mu(1-p)-\beta B(t, k)] n(t, k) \\
+ & \frac{p \mu}{2} \frac{\partial^{2} n(t, k)}{\partial k^{2}} \\
\frac{\partial B(\mathrm{t}, k)}{\partial t} & =\alpha n(t, k) B(t, k)
\end{aligned}
$$

によって近似される．時刻 $t=0$ に抗原型 $k=0$ の病原 体が初期密度 $N_{0}$ で感染したとして, 初期条件は $n(0$, $k)=N_{0} \delta(k)$ と $B(0, k)=B_{0}$ である. これと類似の方 程式は, 数理生態学において，2 種の生物(捕食者と 䬣生物など）が増殖や捕食をしながら一次元空間上を 搪散していくモデルとして詳細に研究されている(た とえば文献 9)１4）参照）今の場合，隣の棲息場所 への移動は突然変異による新しい抗原型の出現に対応 し，また突然変異の大部分が有害であるために，增殖 率と拡散係数とが負に相関している.

病原体と免疫系との動態(2)の平衡状態は，病原体の 突然変異率 $\mu$ と, 新しい抗原型を持つ病原体の初期增 殖率,つまりその抗原に対する抗体がまだ少ないとき の增殖率 $R_{0}=r-\beta B_{0}$ とによって決まる.

(i) 病原体の突然变異率には臨界值が存在する，突然 変異率が臨界值

$$
\mu c=R o /(1-p)
$$

を越えると，有害突然変異による損失が大きすぎて病 原体は寄主体内から駆逐される. (ii) 突然変異率が臨 界值 $\mu c$ 以下であれば，病原体抗原型の分布は一定の 速度 $v$ の進行波解 $(n=n(k-v t), B=B(k-v t))$ k収束す る.つまり奇主体内で病原体の抗原変異の分布 $n(k, t)$ は一定速度 $v$ の孤立進行波として抗原型空間上を“伝 播”し，免疫応答の波が同じ速度でそれを追い続ける. これは，病原体が抗原型を次々と変えることによって 持続的感染に成功する状況に対応している（抗原浮動 解, 图 1$)$. 抗原変異の進行波速度は

$$
v=\sqrt{2 p(1-p) \mu(\mu c-\mu)}
$$

で与えられ, 突然変異率が臨界値 $\mu c$ の半分のときに 最大になる。 


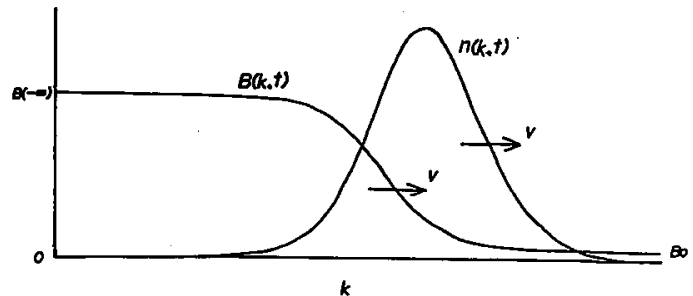

図 1. 抗原型空間 $(k$ 軸)上の病原体抗原变異分布 $n(t, k)$ と免疫応答 $B(t, k)$ の進行波.

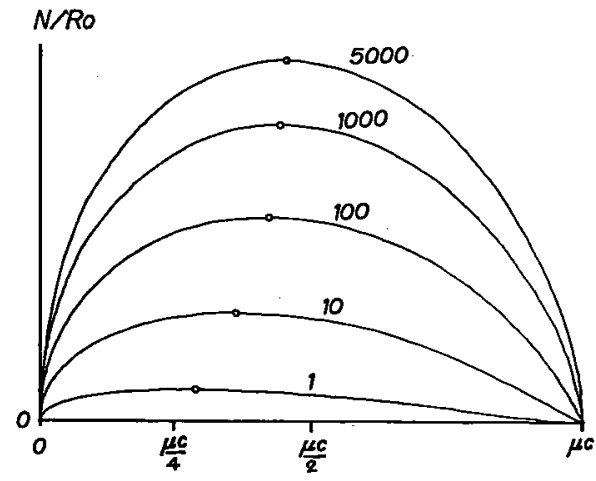

図 2. 抗原型分布が進行波に収束したときの病原体総密 度 $N$ と突然変異率 $\mu$ との関係. $N$ は $\beta B_{o} \operatorname{lexp}(\alpha$ $N / v)-1]=(r-(1-p) \mu) \alpha N / v$ から求めることがで きる(記号は式(2)-(4)参照). 曲線上の数値は $R_{0}$ の值を，Oはそれぞれの $R_{0}$ の值に対して $N$ が最 大になる点を表す。

抗原変異の分布が進行波に収束したとき，病原体の 抗原型はもちろん变り続けるのだが, 病原体の総密度 は定常值に達する．定常密度は突然変異率が 0 と $\mu c$ の間にあるとき正であり，突然変異率 $\mu$ の関数として 上に凸の単峰型である（図 2），突然変異率が低すぎ ると病原体は免疫系の妨御機構からうまく逃九ること ができないし，突然変異率が高すぎると致死突然変異 による内的增加率の堿少がはなはだしく、いずれの場 合も病原体は低密度に押えられるからである．定常密 度を最大にする突然変異率は, 初期增殖率 $R_{0}$ の大き い病原体では臨界值 $\mu c$ のほほ半分, $R o$ が小さい場合 は臨界值のほほ1/4である。

\section{突然変異率の進化}

病原体の突然変異率が寄主体内の個体群動態に大き く影響することはわかったが，それではいったいどん な突然変異率の值が進化するのだろうか. まず，一般 に病原体の形質がどんな方向に進化するかを考えてみ
よう.

病原体の形質は，以下のような過程をへて進化する と考えられる.(1)ある寄主個体に感染したのち，少し でも多くの寄主個体に新たに伝染することができるよ うな病原体の系統が出現すると，それは病原体集団に 広がって他の系統を駆逐する.(2)長い年月の間に，突 然変異によってさまざまな形質を持つ系統が生じ，そ れらの系統の間でこのような競争が繰り返される. (3) その結果，最終的には，感染した寄主個体からの総伝 染数を最大にするような系統だけが残る．そのような 系統が病原体集団の全体を占めていると，他のどんな 系統もその集団に侵入できない．これを“進化的に安 定な状態” (evolutionarily stable state, ESS) という. 現存する病原体のほとんどは，過去に出現したさまざ まな系統の挑戦を退けてきたものであり，したがって 進化的に安定な状態にあると期待される.

こうして，病原体は，感染した寄主個体からの総伝 染数を最大にする方向，つまり感染した寄主が死ぬま での間にその寄主から他の寄主個体に伝染する病原体 の総数を最大にする方向に進化する.

さて，病原体が寄主体内で增殖してその密度が増す と, 単位時間あたりに伝染する病原体の数は增加する. したがって，感染した寄主個体のなかでの定常密度を 最大にするような突然変異率を持つ系統は，他のどん な系統の侵入をも許さないと考えられる。つまり，進 化的に安定な（ESS）突然变異率 $\mu_{E S S}$ は定常密度を 最大にするものであり，したがって臨界突然变異率 $\mu c$ の $1 / 4$ から $1 / 2$ の值である.

臨界突然変異率 $\mu c=R_{0} /(1-p)$ とは, どの程度の

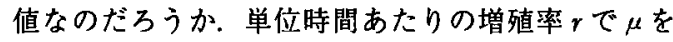
割ってやれば複製あたりの值になる．ほとんどの突然 変異が有害致死である $(p \ll 1)$ と仮定しているから, 複 製あたり突然変異率が 1 というのが臨界值である。こ れは，複製された病原体ゲノムの平均してどこか一ケ 所に突然変異がふる状態，いいかえると，複製された ゲノムのほとんど全部が不良品になる状態に相当する. 突然変異率がこれを越えると病原体が自らを維持でき ないという状況は正に Eigen のエラー・カタストロフ に対応している゙ .

ところで，“逃げ続ける病原体”の最適な突然㡅異

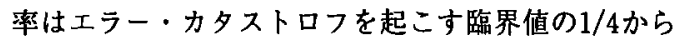
1/2という非常に高い值である.つまり，たとえほと んどの突然変異が有害であっても，生産されるほぼ半 数近くのゲノムができそこないになるような状態が進 化的に安定であり，もっと複製精度の良い病原体が出 
現したとしてもそれは駆逐されてしまう.

これは，突然変異ははとんどが有害なのでできるか ぎり小さい值へと進化する ${ }^{16)}$ という従来の集団遺伝学 の常識と大きく異なる結果である.この“常識”はし かし環境が変動しないという仮定に立脚しており，も し環境の変動によって好適な遺伝子型が絶えず変化す るとすれば，環境の変動率や変動の巾に応じて正の突 然変異率が進化するのは当然であろう ${ }^{17)}$. 今考えてい る状況では，同じ遺伝子型にとどまっているのは寄主 免疫系に攻撃されて非常に不利であるため, それがど んなに危険であっても突然変異率を上げざるを得ない のである，病原体の多くはむしろこのように“進化し つづけないと絶滅する”状況に追い込まれているので はないか。

\section{ウイルスのゲノムサイズと ESS 突然変異率}

以上の結論からウイルスの分子進化について何がい えるだろうか. ウイルスゲノム中の非同義座位の総数 (以後ゲノムサイズと呼ぶ)をLとしよう．このう ち，表面抗原をコードする遺伝子内にある抗原決定座 位の数を $p L$ とし，ここに生じた突然変異はすべて抗 原型の変更をもたらすとする. 残り $(1-p) L$ の非同義 座位に生じる突然変異住全て有害致死であると考えて みる.こう仮定すると今のモデルとうまく対応がつく， 塩基座位あたりに換算した臨界笑变異率は $U c=1 / L$ (/複製) であり, ESS 突然変異率は $U_{E S S}=1 / 4 L$ $1 / 2 L$ (/複製)である.

RNA ウイルスのゲノムサイズはほぼ数干から1万 塩基であるが, 仮にゲノムサイズ $L=5 \times 10^{3}$ 塩基のウ イルスが抗原型を変えつづけることによって持綕的感 染を行っているとしょう。この理論を適用すると, 突 然変異率は $U c=2 \times 10^{-4}$ (/複製/塩基）を越えられず, また $U_{E S S}=0.5 \sim 1.0 \times 10^{-4}$ (/複製/塩基）に進化する はずである。これらが RNA 複製酵のミスコピー率 とほほ等しいことは注目すべきである。

分子進化速度については，抗原決定座位の進化速度 と同義座位の進化速度の比が $\sqrt{2 / p}$ になることがわか る. 抗原決定座位では同義座位よりも進化が速く，そ の比はたとえば $p=0.1$ のき約 4.4 倍, $p=0.01$ のと き約14倍であると予測される.

\section{モデルの拡張}

上記の基本モデル(2)の条件を変えた時の結論を簡単 にふれておく.

(A) 複数の系統が重複感染するとき

同じ奇主個体にしばしば複数の系統が重複感染して
競合するような場合には, 進化的に安定な突然変異率 が上昇し，抗原変異の進行波速度(4)を最大にする突然 変異率 $\mu c / 2$ に近づく.

\section{(B) 無限アレルモデル}

抗原型が一次元格子空間に並んでいるという仮定の かわりに, 突然変異で生じた新しい抗原はすべて異 なっている場合を考える，突然変異が起こるたびに新 しい抗原型がどんどん枝分かれしていくので，抗原型 空間は樹状構造をなす.どの抗原型も同等であると仮 定すると, 病原体と免疫系の動翣をうまく解析できる. 図 3 に病原体総密度の定常值を突然変異率 $\mu$ とその有 害さの度合 $1-p$ の関数として等高線であらわした.

臨界突然変異率 $\mu_{1}$ は(3)にほほ等しく, 定常密度は 0 と $\mu_{1}$ の間で最大になる。 このように, 突然変異の モードに関して非常に異なる仮定をおいても，前の結 果は定性的にはほぼ再現される。

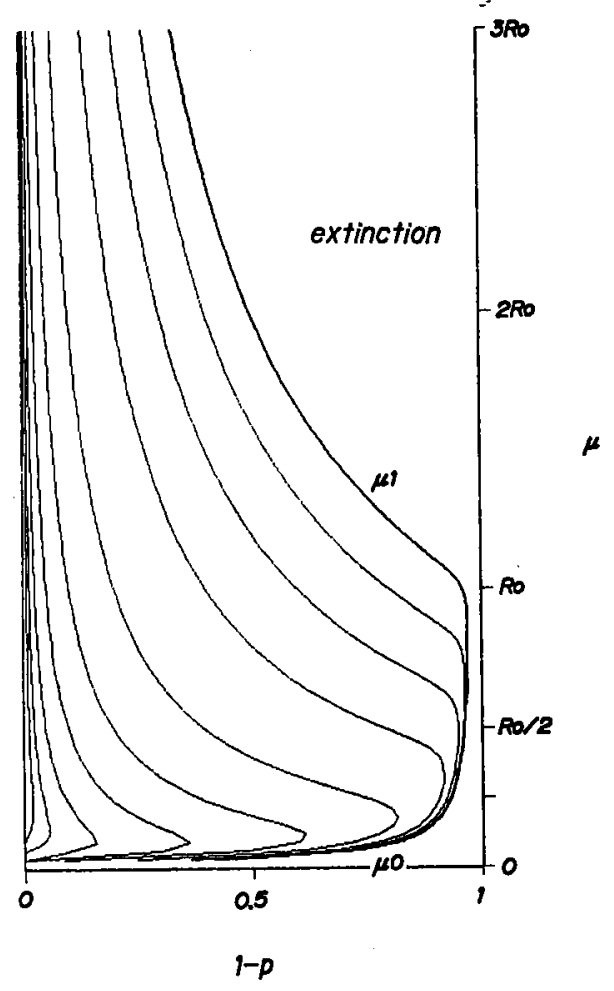

图 3、突然変異によって作られる抗原型はすべて新しい と仮定した場合（無限アレルモデル）の，病原体 棯密度の定常值 $N$ と突然変異率 $\mu$, 有害突然変 異の割合 $1-p$ との関係. 曲線は $N$ の等高線を表 し, 外側の太い曲線が $N=0$ の等高線でその外側 の領域では病原体は絶㙎する. $\mu_{0}$ と $\mu_{1}$ は，与え られた 1ーpに対するふたつの臨界突然変異率. 


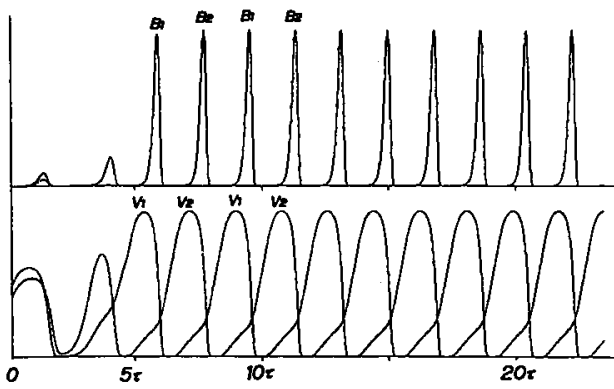

图 4、病原体ゲノム中の抗原変異のレパートリーの数が $2(K=2)$ の場合の，それぞれの抗原型をもつ病 原体の体内密度 $V_{1}$ と $V_{2}$ と，それに対応する抗体 産生細胞の密度 $B_{1}$ と $B_{2}$ の時間変化. 時間軸は免 疫応答の時間遅れ $\tau$ を単位に測っている.

（C）抗原スイッチ一抗原レパートリーが少ない場合 以上のモデルでは変異しうる抗原型の数が潜在的に は無限個ある場合を扱ってきた，しかし，抗原スイッ チを行う病原体のなかにはゲノム内の抗原レパート リーの数が非常に少ないものがある一例えば，サルモ ネラ菌やファージ $\mu$ の場合はたったの 2 個にすぎない. そこで抗原型は有限個 $K$ しかなく，抗原スイッ千は $K$ 個のレパートリーの間で均等に起こるとする.

病原体か存続するためにはゲノム中の抗原レパート リーの数 $K$ がある臨界数 $K c$ よりも多くないといけな い. 寄主の免疫機構が強力であるほど, 病原体は存続 するために多くの抗原レパートリーを備えておく必要 がある.

また，免疫応答の時間遅れが大きくなると，病原体 の密度と B 細胞の密度とがともに時間的に振動する ようになる. 図 4 に示されるように，B細胞の密度が 一定の間隔をおいて間欠的に跳ねあがるのがわかる. このピークは高熱状態に対応するので，これは病原体 の抗原型が巡回的に入れ換わるたびに高熱がぶり返す ことを示している.

そのほか, 病原体が低密度のときのゆらぎの効果な ども計算できる.

\section{病原体の最適增殖スケジュール}

よく、「病原体はしだいに寄主にとって無害になる ように進化する」と言われることがあるが，これは誤 りである. 突然変異率に限らず, 病原体の伝染率やビ ルレンス（病気による寄主死亡率）なども総伝染数を 最大にする方向に進化するのであって，ビルレンスが 他の疫学的パラメーターとどう相関するかに応じて, 総伝染数を最大にするビルレンスの值も異なってくる.
例として，ウサギの駆除のためにオーストラリアに導 入されたミクソーマウイルスの進化を見てみよう，導 入された当初は非常に高かったミクソーマウイルスの ビルレンスはしだいに低下するが，中間の值で進化的 な定常状態に達した ${ }^{18}$.これは,ビルレンスが伝染率 や病気からの回復率と相関しているためであり，これ を考虑して感染した寄主個体加の総伝染数を最大に する方向に進化すると考えるとうまく説明できる

このような考察を押し進めて，寄主に感染したのち の病原体の多様な振舞い一增殖スケジュール一の進化 を考えてみよう，增殖によって病原体の体内密度が增 すと，単位時間あたりの病原体伝染率は增加するが， せっかく感染した寄主の死亡率も上昇して将来の感染 の機会が減ってしまう。したがって，寄主内密度を上 げることが，病原体にとって常に有利とは限らな $\left(^{200-223}\right.$ ．密度増加による将来の不利益を上まわる利益 が見込めるときだけ病原体は增殖すべきなのである.

総伝染数を最大にするような，病原体の寄主内での 最適増殖スケジュール 下のようなことがわかる（i）病原体は，健康で若い 寄主に対してはおとなしく，病弱で老齢の奇主に対し ては過酷に振舞うのが有利である．どうせ先の見込め ない寄主に対しては今のうちにせいぜい増殖して感染 率をあげたほうがいいからである.(ii) 空気感染や経 口感染によって伝わる病原体（インフルエンザウイル スやコレラ菌など）は増殖することによって感染率が 効果的に上昇するので，感染後はひたすら增殖するの が最適スケジュールになる．しかし，接触感染によっ て感染する病原体（例えば HIV-1）は感染率が密度 とともに飽和しゃすいので体内で一定の密度に達した あとは増殖を制限して長く潜伏するのが有利である。

(iii) 母乳感染などによって感染者の子供に伝わること のできる病原体（ATLウイルスなど）は，寄主の繁 殖期まではできるだけ病原性をおさうて寄主を生かし ておき，繁殖期が終る頃から活発な增殖をはじめるべ きである. (iv) 病原性の高い他の病原体が感染すると それまでおとなしくしていた病原体も破壊的增殖を開 始すべきである．したがって，日和見感染と呼ばれる 現象や，潜伏状驡にある HIV- 1 が EB ウイルスなど の感染に伴って增殖サイクルに入ることなどは ${ }^{24)}$, 病 原体の最適增殖という観点からみて理にかなったもの であるのがわかる.これらの話題に興味がある読者は 総説 $^{25)}$ を参照していただければ幸いである。

ここでとりあげたのは，病原体の多彩な戦略のほん の一端にすぎない，病原体が糄み出した戦略をひとつ 
ひとつ解明することによって，我々は進化のタイイ ミックスと法則性について，はかりしれない知識を得 ることができるのではないかと考えている。

\section{文献}

1) Turner, M. J.(1987) In "Antigenic Variation in Infectious Diseases." T.H. Birkbeck and C. W. Penn(eds), pp.1-17, IRL Press, Oxford

2) van der Ploeg(1987)Cell 51, 159-161

3) Birkbeck, T. H. and Penn, C. W. (eds) (1986) "Antigenic Variation in Infectious Diseases." IRL Press, Oxford

4) Borst. P., Greaves, D.R.(1987) Science 235, 658-667

5) Montelaro, R.C., Issel, C.J., Payne, S., Salinovich, O.(1986) In: Antigenic Variation in Infectious Diseases, T.H. Birkbeck and C.W. Penn(eds), pp.41-56, IRL Press, Oxford

6) Haase, A.T.(1986) Nature 322, 130-136

7) Hahn, B., Shaw, G.M., Taylor, M.E., Redfield, R.R., Markham, P.D., Salahuddin, S.Z., Wong-Staal, F., Gallo, R.C., Parks, E.S., Parks, W.P.(1986)Science 232, 1548-1553

8) Sasaki, A.(1989)Doctor Thesis of Kyushu University.

9) Levin, S.A.(1976)Ann. Rev. Ecol. Systematics 7. 287-310.

10) Fife, P.C.(1979)Lect. Notes Biomaths.28, 1-185

11) Okubo, A. (1980) "Diffusion and Ecological Problems:
Mathematical Models." Springer, New York.

12) Shigesada, N., Kawasaki, K., Teramoto, E. (1986) Theor. Pop. Biol. 30, 143-160

13）瀬野裕美(1989)生物物理 29. 203-207

14) Yachi, S. Kawasaki, K., Shigesada, N., Teramoto, E. (1989) Forma 4, 3-12

15) Eigen, M.(1971)Natunwissenschaften 33a, 465-523

16) Lieberman, U., Feldman, M. (1986) Theor. Pop. Biol. 30, 125142

17) Ishii, K., Matsuda, H., Iwasa, Y., Sasaki, A.(1989)Genetics $121,163-174$

18) Fenner, F.(1965)In "The Genetics of Colonizing Species," H.G. Baker and G.L. Stebbins (eds), pp.485-499, Academic Press, New York

19) May, R.M., Anderson, R. M. (1983) Proc. R. Soc. Lond. B 219, 281-313

20) Eshel, 1.(1977)Theor. Pop. Biol. 11, 410-424

21) Axelrod, R., Hamilton, W.D.(1982)Science 211, 1390-1396

22) Bremermann, H. J., Pickering, J. (1983) J. theor. Biol. 100 , 411- 426

23) Sasaki, A., Iwasa, Y.(1990)Theor. Pop. Biol. (in press)

24) Fausi, A. S.(1988) Science 239, 617-622

25）佐々木顕(1989)個体群生態学会会報 45, 11-22 などを転々とする．京大理学部・寺本研で学部卒業までお世話にな ク，1984年から九大理学部・数理生物学講座へ. 1989年より同講座 助手. 幼稚園以来マスターした楽器は10数種類に及ぶ (トライアン グルを含む). 熱気球をやっていた関係で気象学・流体力学・内撚 機関などにも興味がありますが，現在はやはり遺伝子と文化の進化 が面白い，適当な材料でカクテルをつくり，他人に飲ませることが あります。

T812 福岡市東区箱崎 6-10-1 九大理学部生物

ฮ092-641-1101 内線4438 FAX 092-632-2741 